\title{
Catalysts for Oxygen Reduction Reaction in the Polymer Electrolyte Membrane Fuel Cells: A Brief Review
}

\author{
Martin Tomas $^{1, *(\mathbb{D})}$, Fatemeh Gholami ${ }^{1}\left(\mathbb{D}\right.$, Zahra Gholami $^{2}(\mathbb{D})$ and Jan Sedlacek ${ }^{1}(\mathbb{D}$ \\ 1 New Technologies-Research Centre, University of West Bohemia, Veleslavinova 42, \\ 30100 Plzen, Czech Republic; gholami@ntc.zcu.cz (F.G.); sedlacek@ntc.zcu.cz (J.S.) \\ 2 Unipetrol Centre of Research and Education, a.s., Areal Chempark 2838, Zaluzi 1, \\ 43670 Litvinov, Czech Republic; Zahra.Gholami@unicre.cz \\ * Correspondence: mtomas@ntc.zcu.cz
}

check for updates

Citation: Tomas, M.; Gholami, F.; Gholami, Z.; Sedlacek, J. The Catalysts for Oxygen Reduction Reaction in the Polymer Electrolyte Membrane Fuel Cells: A Brief Review. Electrochem 2021, 2, 590-603. https:// doi.org/10.3390/electrochem2040037

Academic Editor: Masato Sone

Received: 29 September 2021

Accepted: 19 October 2021

Published: 22 October 2021

Publisher's Note: MDPI stays neutral with regard to jurisdictional claims in published maps and institutional affiliations.

Copyright: (c) 2021 by the authors. Licensee MDPI, Basel, Switzerland. This article is an open access article distributed under the terms and conditions of the Creative Commons Attribution (CC BY) license (https:// creativecommons.org/licenses/by/ $4.0 /)$.

\begin{abstract}
This mini-review presents a short account of materials with exceptional activity towards oxygen reduction reaction. Two main classes of catalytic materials are described, namely platinum group metal (PGM) catalyst and Non-precious metal catalyst. The classes are discussed in terms of possible application in low-temperature hydrogen fuel cells with proton exchange membrane and further commercialization of these devices. A short description of perspective approaches is provided and challenging issues associated with developed catalytic materials are discussed.
\end{abstract}

Keywords: PEMFC; catalyst; ORR; platinum

\section{Introduction}

Fossil fuel generation is gradually replaced with renewable energy generation to decrease the $\mathrm{CO}_{2}$ emission of the power system. Electrical energy storage (EES) is one of the required new technologies for the energy generation industry [1-3]. The efficiency and operation cost of the EES system is determining by thir performance. The critical goal of using EES is reducing the negative impact on the environment, capital and operating cost and ensuring durability. The type of the storage device depends on the energy being stored. Electrical storage systems can be classified into mechanical, electrochemical, chemical and thermal storage systems [4].

Chemical energy storage systems is classified into hydrogen and biofuels. The hydrogen storage systems include different categories: hydrogen pressurization and absorption of metal hydrides, adsorption of hydrogen on carbon nanofibers and liquefaction of hydrogen. Low pressure, compatibility and high absorption rate are the advantages of this storage system [5].

Another way of producing hydrogen is electrolysis of water and use with a fuel cell. The stored hydrogen gas can be used in a fuel cell where oxygen and air are oxidants. Fuel cells are energy converting devices that produce electrical energy directly from the chemical energy in the fuel. Water and thermal management of fuel cells are critical, as they control the cell's overall performance. The required reactant for electricity generation is externally supplied. Fuel cells are environmentally friendly and usually produce electricity without noise due to the absence of moving parts. Fuel cells are ideal for energy management and power quality, making them suitable in the automotive industry. The various types of fuel cells are based on the type of electrolyte, cell operating temperature and the fuel used in its operation, e.g., phosphoric acid fuel cell (PAFC), alkaline fuel cell (AFC), polymer electrolyte membrane fuel cell (PEMFC), molten carbonate fuel cell (MCFC) and solid oxide fuel cell (SOFC) [4,6].

The fuel cells provide a clean, efficient and probably the most flexible conversion of chemical energy to electricity [7-10]. Proton exchange membrane fuel cells (PEMFCs) are generally considered to be one of the most promising types of renewable energy sources 
which allow an emmission-free conversion of chemical energy into electrical power [11,12]. In the last two decades, a tremendous effort has been made in order to radically decrease the amount of platinum group metals (PGM) loading on the cathode side of the PEMFCs [13]. A sluggish kinetics of oxygen reduction reaction (ORR) at the cathode side-difficult $\mathrm{O}_{2}$ activation, $\mathrm{O}-\mathrm{O}$ bond cleavage and oxide removal-is limiting the further development of PEMFCs and other types of fuel cells such as direct methanol fuel cells (DMFCs) [14]. This well-known issue was addressed by many groups of researchers, thus the developed catalysts advance the path towards the process of fuel cell commercialization. So far, the fuel cells are successfully used as energy sources for backup power supply, material handling (forklifts) and portable applications. However, the breakthrough in automotive industry is yet to come.

The ORR proceeds in two ways. One of them is direct four-electron transfer which results in the formation of the water molecule, see Figure 1. This pathway is favourable, however, the series of two-electron transfers can occur and leads to formation of hydrogen peroxide [15]. Some other intermediates are produced too, namely $\mathrm{O} \bullet, \mathrm{OH} \bullet$ and $\mathrm{OOH} \bullet$, which cause the membrane degradation [16]. The reaction pathway depends on the oxygen coverage of the catalyst; high coverage induces higher hydrogen peroxide production [14]. Then, the formed $\mathrm{H}_{2} \mathrm{O}_{2}$ causes the carbon support corrosion or bipolar plates degradation. In the case of non-fluorinated membranes, the $\mathrm{H}_{2} \mathrm{O}_{2}$ causes membrane thinning and creates pinholes or cracks. The direct four-electron transfer in acidic electrolyte can be expressed as [17]

$$
\mathrm{O}_{2}+4 \mathrm{H}^{+}+4 \mathrm{e}^{-} \rightarrow 2 \mathrm{H}_{2} \mathrm{O} \quad 1.229 \mathrm{~V} \text { vs. NHE }
$$

and the indirect two-electron transfers proceeds as follows

$$
\begin{array}{cc}
\mathrm{O}_{2}+2 \mathrm{H}^{+}+2 \mathrm{e}^{-} \rightarrow \mathrm{H}_{2} \mathrm{O}_{2} & 0.67 \mathrm{~V} \text { vs. } \mathrm{NHE} \\
\mathrm{H}_{2} \mathrm{O}_{2}+2 \mathrm{H}^{+}+2 \mathrm{e}^{-} \rightarrow 2 \mathrm{H}_{2} \mathrm{O} & 1.76 \mathrm{~V} \text { vs. NHE }
\end{array}
$$

The kinetics of ORR is approximately 5 orders of magnitude slower compared to hydrogen oxidation reaction (HOR) occurring at the anode.

On the other hand, the loading of platinum-based or PGM catalysts in the fuel cell decreased significantly [18]. Nowadays, the units with a total amount of PGM of around $10 \mathrm{~g}$ are produced [19]. So that, the amount of precious metals is comparable to the amount of these metals used in vehicles with internal combustion engines (ICE), where the PGM is needed for catalytic reduction of flue gas (exhaust gas converter for cleaning duty). Obviously, the cost of a fuel cell unit in the car is mostly related to other components namely bipolar plates. As commercialization through mass production proceeds, the cost of fuel cell components is ought to decrease with exception of platinum catalysts.

On account of the low earth abundance of platinum and related cost volatility, the research of catalysts for the hydrogen fuel cells is focused on the platinum replacement and the decrease of loading. Many types of catalysts have been proposed as promising candidates for commercial fuel cell units. The main problem of these materials is the difference between in-situ and ex-situ properties. Many of these materials demonstrated extraordinary mass activities, but after the fabrication of membrane electrode assembly (MEA), lower than expected performance was observed. Moreover, a remarkable Beginning of Life (BoL) performance quickly decreased and the stability/durability problem seems to be crucial for many of these catalysts [14]. So far, the research activities in catalyst development may be divided to two broad groups: Platinum group metal catalysts (PGM) and Non-precious metal catalysts. 


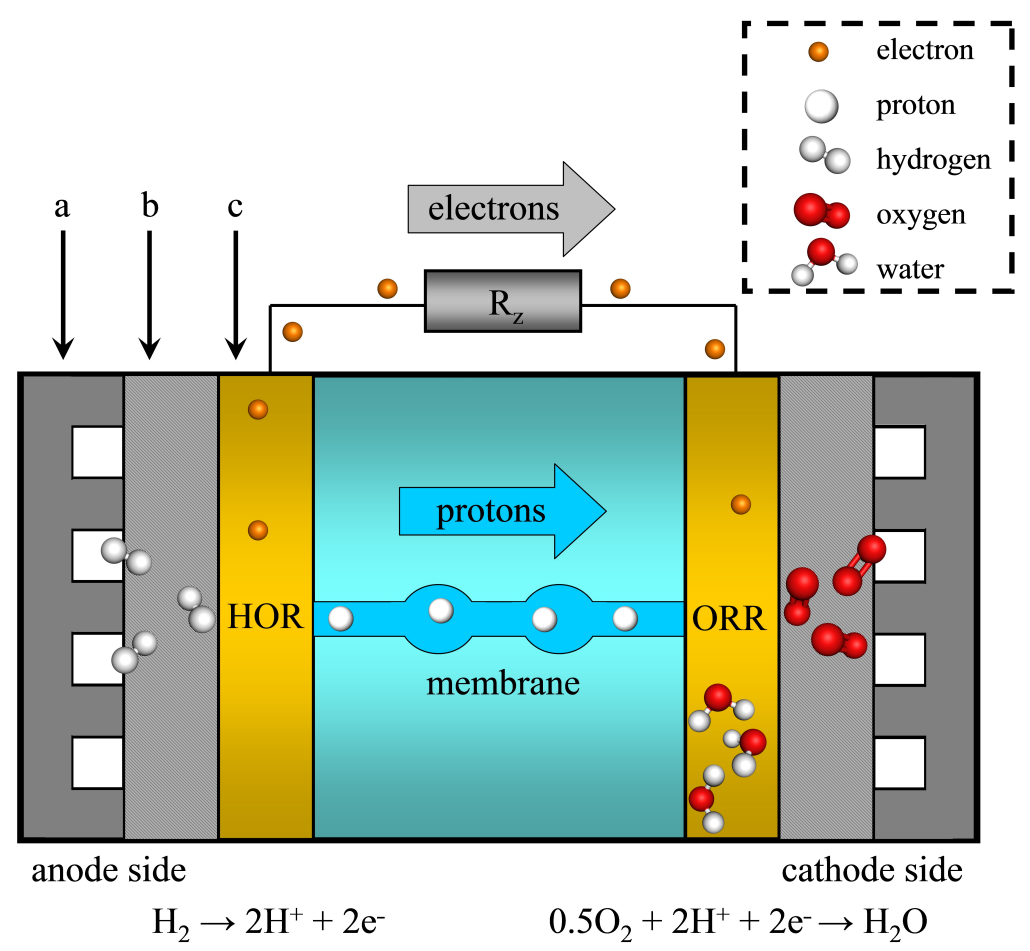

Figure 1. Illustration of a hydrogen fuel cell depicting main components, namely: (a) A bipolar plate with ribs feeding the fuel cell with the reactants. (b) A gas diffusion layer (GDL) providing homogeneous distribution of the reactants. (c) An anodic catalytic layer. The central part of the fuel cell is a membrane with proton conducting channels. The polymer electrolyte used in fuel cells acts as a semi-permeable membrane allowing protons to pass through to the cathodic side. But the electrical conductivity of the membrane is low, so the electrons liberated at the anodic side generate work in the external circuit. The cathodic side of the fuel cell is symmetrically arranged, so the cathodic bipolar plate, GDL and catalytic layer are depicted in the same manner. The ORR takes place in cathodic catalytic layer. The symbol $\mathrm{R}_{\mathrm{z}}$ denotes an electrical load.

\section{Platinum Group Metal Catalyst (PGM)}

Limiting factor of PGM catalyst is interaction of the metal alloys and supporting material. The performance loss caused by fading of catalyst nanoparticles can be observed after a few hundred hours of fuel cell operation. To overcome this problem, the promising catalyst surface modifications, e.g., highly ordered core-shell structure, in-situ carbonized carbon and organic functional groups, have been proposed. The synergic effects between platinum and other metals provides improved catalytic activity and $\mathrm{CO}$ tolerance. The effect is based on higher $\mathrm{CO}$ desorption rate and specific open structure with more active sites exposed to fuel [20]. The structures involve nanowires, nanoplates, nanoframes and other 3D structures, e.g., concave polyhedrons prepared by capping agents and selective corrosion [21]. The synthesis methods include colloidal deposition, co-reduction, galvanic replacement reaction, seeded growth and pyrolysis.

\subsection{Platinum and Pt-Based Catalysts}

Generally, the platinum in a form of nanoparticles dispersed at the surface of the carbon support, e.g., carbon black, carbon nanotubes or graphene, is the most widely used material for hydrogen fuel cell catalyst [22,23]. The carbon support possesses excellent electrical conductivity, high surface area, satisfactory porosity and low cost. The stability in acidic electrolytes and high mass activity make the platinum suitable for cathodic and anodic catalytic layer of the membrane electrode assembly (MEA). However, the carbon support can suffer from electrochemical oxidation and the platinum particle agglomeration was observed, which leads to the loss of superior activity. Moreover, a homogenous dispersion of platinum nanoparticles (and other delicate catalyst nanostructures) is distorted 
by Ostwald ripening and that results in further loss of active surface [20]. At higher performances of a fuel cell, the generated water can wash out the catalytic material causing the migration of particles out of the desired location. These types of the degradation are inevitable in fuel cell cars, where the high current density needs to be produced. Furthermore, the high purity hydrogen is needed for optimal operation of the fuel cell. A contamination of reactants by carbon oxides, nitrogen oxides, sulfur oxides, ammonia or hydrogen sulfide steeply decreases the performance of a fuel cell. The platinum particles can be blocked by carbon monoxide or poisoned by adsorption of sulfur-based moieties and no longer contribute to electrochemical reactions. Lower concentrations of contaminants cause reversible performance decrease, but the high concentration of carbon monoxide leads to irreversible diminution of catalytic performance.

The mass activity of the Pt catalyst can be enhanced by two main factors-the particle size and the particle shape. A maximum dispersion of platinum is obtained if the single atom acts as an active site. This single-atom catalyst was succesfuly prepared by several groups, but the issues related to stability and deactivation remain $[17,24]$. The shape of the many-atoms particles seems to be crucial too. The investigation of the particle shape was focused mainly on the facets with low Miller indices, i.e., $\operatorname{Pt}(100), \operatorname{Pt}(110), \operatorname{Pt}(111)$, but some other forms of platinum were prepared as well [25]. However, the particles with higher Miller indices are difficult to prepare in some reasonable amount [14].

Alloying Pt with transition metals $(\mathrm{M})$ has attracted attention recently as promising materials to reduce the use of Pt. Studies have shown that combining Pt with transition metals affects the position of the d-band center of $\mathrm{Pt}, \mathrm{d}$-bandwidth and influences the interaction between the electrocatalyst surface and adsorbed intermediates results in optimized electrocatalytic activity. However, the catalytic activity by alloying $\mathrm{Pt}$ with transition metals is remarkable, but the leaching of transition metals under strong-acid and high-potential operating conditions of PEMFCs would considerably reduce the ORR performance. In addition, the dissolved transition metals, such as Fe and $\mathrm{Co}$, in the electrolyte would contribute to the Fenton reactions and degrade the ionomers of the PEMFC. Based on the crystal structure, the alloys of Pt-M can be categorized into disordered phase (solid solution) and ordered phase (intermetallic compound). The disordered phases have varying surface compositions and randomly distributed active sites because the atomic positions are occupied randomly by $\mathrm{Pt}$ and $\mathrm{M}$. Ordered phase or intermetallic compounds have a uniform distribution of active sites on the surface plane due to their well-defined stoichiometry and better control of local geometry of metal atoms [26,27].

The bimetalic alloys of platinum can decrease the amount of scarce platinum and enhance the stability of the catalyst [28,29]. The alloys of $\mathrm{Pt}$ with metals such as $\mathrm{Ni}, \mathrm{Fe}$, $\mathrm{Co}, \mathrm{Pd}, \mathrm{Ru}, \mathrm{W}$ and $\mathrm{Ti}$ were prepared and their properties were examined [30,31]. Some of the alloys have been used in fuel cell cars, e.g., PtCo in Toyota Mirai [32]. So far, the promising results were achieved when Pt is alloyed with iron or nickel [33-36]. In the fuel cell, iron acts as a Fenton reagent, so the presence of this element should be restricted to catalytic layer. Otherwise, the serious damage of the membrane and other components is caused by harmful by-products (hydrogen peroxide) of undesired reactions. In addition, the transition metals alloyed with platinum are prone to leach or dissolve in relatively harsh environment of a fuel cell [37]. On the other hand, Pt-Ru and Pt-Cr alloys are more immune to the CO poisoning $[38,39]$. The alloys of platinum and gold were also investigated and the samples exhibited higher mass activity and stability compared to pure platinum [20].

\subsection{Core-Shell Catalysts}

A sophisticated step towards the better utilization of platinum has been achieved by deposition of this expensive metal on a cheaper core (core-shell nanoparticles), see Ref. [40] and references therein. The high surface area of active catalyst can be realized by layering the platinum on the core made of metals such as palladium, yttrium, scandium, chromium or titanium (Figure 2) [41]. Single metals as well as binary or ternary alloys can be employed as core materials. The metallic core also influences the electronic structure of the $\mathrm{Pt}$ atom 
and improves the electrocatalytic performance of the material. The core-shell nanoparticles are known for their capacity to weaken the $\mathrm{Pt}-\mathrm{O}$ bond, so that, the electrocatalytic activity of these materials may be extraordinary. Additionally, the durability of the catalysts can be further increased by incorporating non-metals or polymers in the core [42,43]. The attention of the research groups is not limited to the conventional spherical shape of nanoparticles, other structures such as nanorods, nanowires, dendrites, star-like or tree shapes have been investigated too [44].

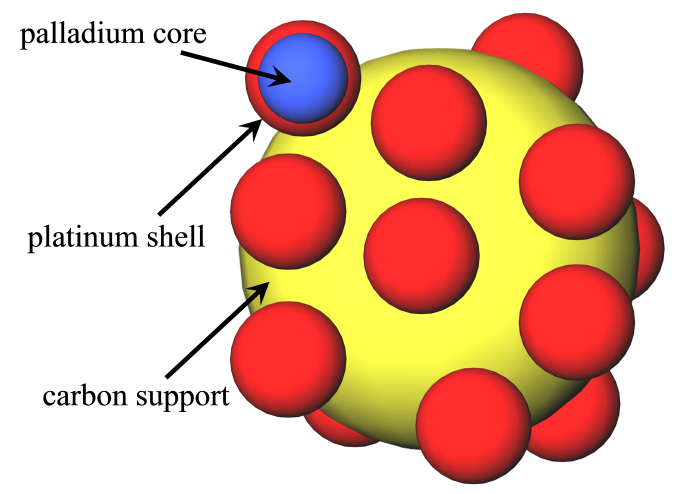

Figure 2. An illustrative depiction of the carbon support with the core-shell nanoparticles (Pt@Pd). The cross-section of the nanoparticle is showed indicating layered platinum (red) on the palladium shell (blue).

The activity of core-shell nanoparticles and the elegance of the catalyst structure have attracted many research groups [45-49]. It has been reported, that a monolayer of $\mathrm{Pt}$ atoms can be formed on the surface of the core [50]. Thus, the maximum utilization of the platinum can be achieved. Moreover, the solid core can be dissolved and a hollow coreshell particle can be formed [51]. However, the remarkable activities of hollow core-shell nanoparticles steeply decrease by voltage cycling. Furthermore, the collapse of the core or the dissolution of shell material have been observed, so the stability remains the main issue in the research of core-shell catalysts [52,53].

\subsection{Nanocrystals}

The activity of platinum nanoparticles increases with increasing surface area, so smaller particles with high specific surface should be very active towards ORR. This is true up to the particle size of about $2 \mathrm{~nm}$, smaller particles are less active because of the presence of edges and vertices which do not allow efficient four-electron transfer [54]. The problem can be solved by synthesizing atomic planes tuned for desired ORR activity.

It is well-known fact that the catalytic activity of open structured surfaces exceeds the activity of densely packed surfaces [55]. So, the high-index planes are promising geometry for ORR catalyst, but the successful synthesis of desired shape, e.g., tetrahexahedral $\mathrm{Pt}$ nanocrystals, remains difficult. One of the perspective shapes is the $\mathrm{Pt}_{3} \mathrm{Ni}$ octahedral nanocrystal catalyst with remarkable specific and mass activity of about 90-fold more than the activity of commercial $\mathrm{Pt} / \mathrm{C}$ catalyst [56]. Moreover, a controllable $\mathrm{Pt}_{3} \mathrm{Ni}$ synthesis leads to the creation of highly porous nanocrystals with large specific surface areas and interconnected branches [57,58]. In general, Pt-based bimetallic and trimetallic nanocrystals with the same polyhedral type exhibit better ORR activities owing to the addition of another component active for oxygen kinetics in electrocatalysis [59]. Recently, the highly active Pd@Pt-Ir icosahedral nanocrystals were prepared by Zhu and co-workers [60].

All of the above-discussed categories of platinum PGM catalysts demonstrated high activities towards ORR, however, the stability and durability of developed materials remain problematic. Platinum and Pt-based materials are expensive despite their excellent catalytic properties. The core-shell catalysts are often unstable under long-term testing 
conditions and the shape-controlled nanocrystals are difficult to synthesize with welldefined morphology.

\subsection{Carbon and Non-Carbon Supports for PGM Catalyst}

Catalyst support strongly influences the performance of fuel cell membrane electrode assembly as it significantly contributes to key factors such as catalyst utilization, mass transfer, charge transport and durability. The most commonly used support for PGM catalyst are Vulcan XC-72 and Ketjen black. It has been established that spherical carbon particles undergo corrosion at high potentials $(>1.5 \mathrm{~V})$ resulting in the aggregation of $\mathrm{Pt}$ nanoparticles and gradual decrease in the electrochemically active surface area of $\mathrm{Pt}$. Highly graphitized carbon supports are known to be less prone to corrosion at high operating potentials. High surface area, corrosion resistance and suitable morphology to anchor catalytic particles are key attributes of ideal catalyst support. The US DOE support stability target at the MEA level requires less than $30 \mathrm{mV}$ voltage decrease at a current density of $1.5 \mathrm{~A} / \mathrm{cm}^{2}$ after 5,000 cycles from 1.0 to $1.5 \mathrm{~V}$. Many carbon and non-carbon containing catalyst support have been studied to achieve the support stability target set by US DOE. Ceramic supports based on carbides, oxides, nitrides, borides have been studied as catalyst support [61]. However, they offer intrinsically high corrosion resistance, their poor electrical conductivity and low surface areas have prevented their practical use in fuel cell cathodes. The preferred choice of support is still carbon based porous materials. Chen et al. have studied the activity and stability of Pt alloy nanoparticles supported nitrogen doped graphitized carbon nanotubes. These advanced carbon supports exhibited favourable metal-support interaction and after 20,000 potential cycles (0.6-1.0 V vs. RHE), the retained electrochemical surface area (ECSA) is more than 2 times larger than that of the $\mathrm{Pt} / \mathrm{C}$ catalyst [62]. Achieving a balance between high degree of porosity and graphitization is crucial to develop ideal catalyst support materials. Therefore, more careful design, synthetic strategies and testing in fuel cell cathodes are needed to move towards the US DOE support stability target.

\section{Non-Precious Metal Catalyst}

To avoid the usage of precious metals such as platinum, many research groups focused on catalysts based on other materials [63-65]. One of the reasons is the expected reduction in cost of the MEA [66]. For example, in the case of $\approx 500,000$ units produced per year, the estimated cost of catalyst, membrane, gaskets and GDLs might exceed $62 \%$ of the total cost of a fuel cell stack [67]. Catalyst alone is estimated to be $41 \%$ of the total cost, see Figure 3a.

(a)

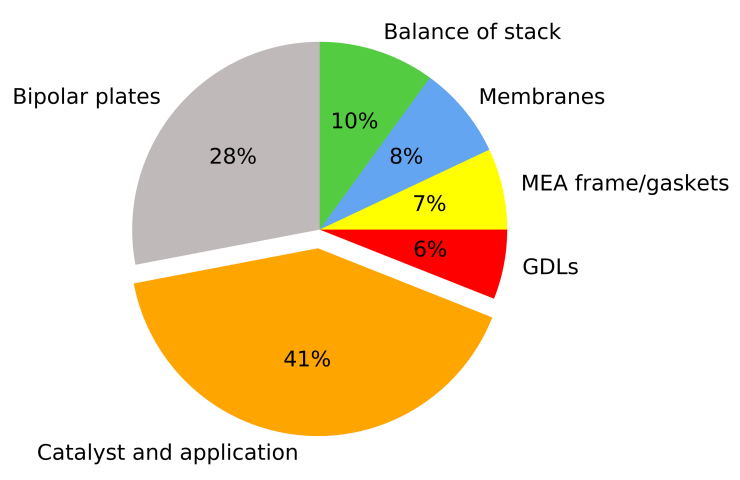

(b)

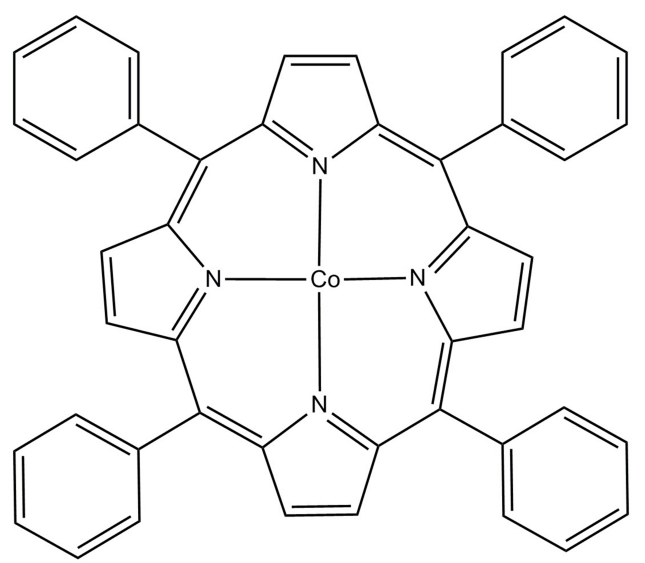

Figure 3. (a) Estimated costs of fuel cell stack components [67]. (b) The illustrational structure of transition metal macrocyclic compound. 
A detailed cost analysis of the most promising PGM-free M-N-C type catalyst suggested that a PGM-free Fe-N-C catalyst costs 200 times less than a Pt-based catalyst (a comparison made using electrodes with the Pt loading of $0.142 \mathrm{mg} / \mathrm{cm}^{2}$ ) [68]. The elimination of Pt from the fuel cell cathode catalyst layers would allow realization of stack cost reduction by $6 \$ / \mathrm{kW}$ (assuming comparable durability) —an important step in a pathway to meet the $30 \$ / \mathrm{kW}$ US DoE target that would boost cost competitiveness of fuel cell electric vehicles. However, at present, the non-precious metal catalysts (NPMCs) are considered furthest from commercialization, because their performace significantly drop after voltage cycling or potentiostatic/galvanostatic experiments [69]. Moreover, the fuel cells used in automotive industry must provide high power density to meet the criteria of the market. The NPMCs exhibit low power density when implemented in the fuel cell, so that, the potential application of these materials is limited to portable applications or backup power sources.

The NPMCs are based on transition metals dispersed on nitrogen-doped carbon [70,71]. Generally, the structure of NPMCs can be expressed as $\mathrm{M}-\mathrm{N}_{(2 \text { or } 4)}-\mathrm{C}$, where $\mathrm{M}$ denotes the transition metal [72]. The typical structure is depicted in Figure $3 b$, the metal atom is coordinated into four nitrogen atoms (metal chelate). The central atom determines the catalytic activity and the surrounding ligand structure can be used for tuning the selectivity, reactivity and other parameters [73]. Moreover, the NPMCs are able to catalyse the ORR in both acid and alkaline media [74]. The Co porphyrin, see Figure $3 b$, has catalytic activity towards the two-electron process, i.e., reactions (2) and (3), however, the ironbased structures allow the four-electron process [75]. Recently, Banham and co-workers have reported the high performance NPMC, which represent an important step in the commercialization of this group of materials [76]. A single atom Fe-N-C catalyst with promising volumetric current density was synthesized by Liu and co-workers [77]. The FeCo-N-C catalyst has been studied by Liang and co-workers and the developed material has been incorporated into the MEA with loading of $4 \mathrm{mg} / \mathrm{cm}^{2}$ [78]. The group obtained an impressive performance of $575 \mathrm{~mA} / \mathrm{cm}^{2}$ at $0.7 \mathrm{~V}$ and remarkable stability. Other types of NPMCs are based on metal oxides, metal nitrides or metal chalcogenides [79].

The synthesis of M-N-C catalyst usually involves few high temperature treatment steps leading to the formation of highly heterogeneous material composed of multiple carbon phases, metal species, limiting our ability to identify the active site and to further discover synthetic strategies to increase the active site density. To overcome this issue and subsequently increase the density of active $\mathrm{M}(\mathrm{Fe} / \mathrm{Co} / \mathrm{Mn})-\mathrm{N}_{4}$ sites, support-free synthesis methods from metal-organic framework type precursors consisting of metal, nitrogen, carbon bonds have been developed. Wu et al. have prepared an atomically dispersed $\mathrm{Mn}$ $\mathrm{N}-\mathrm{C}$ catalyst with high-density $\mathrm{MnN}_{4}$ sites by using Mn-doped zinc imidazolate framework (ZIF-8) as precursors. The optimized Mn-N-C catalyst exhibits high current densities of 0.35 and $2.0 \mathrm{~A} / \mathrm{cm}^{2}$ at 0.6 and $0.2 \mathrm{~V}$, respectively, in PEM fuel cells under $\mathrm{H}_{2} / \mathrm{O}_{2}$ condition [80]. By elimination of the inactive carbon phases ORR activity in acid can be significantly increased, Wan et al. have reported an atomically dispersed single Fe site based Fe-N-C catalyst that exhibits a power density of $1.18 \mathrm{~W} / \mathrm{cm}^{2}$ under 2.5 bar $\mathrm{H}_{2} / \mathrm{O}_{2}$ and an activity of $129 \mathrm{~mA} / \mathrm{cm}^{2}$ at $0.8 \mathrm{~V}_{i R-\text { free }}$ under $1.0 \mathrm{bar} \mathrm{H}_{2} /$ air in PEM fuel cell configuration. It is well documented in literature that the presence of $\mathrm{Fe}$ and peroxide promotes Fenton reaction in fuel cell cathodes generating free radicals resulting in serious degradation of the organic ionomer and the membrane. To address this challenge, nitrogen-coordinated single cobalt atom catalysts for oxygen reduction in PEM fuel cells was developed and reported by $\mathrm{Wu}$ et al. The atomically dispersed Co-N-C catalyst were prepared from Co-doped ZIF-8 and the optimized catalyst exhibited the power density of $0.56 \mathrm{~W} / \mathrm{cm}^{2}$ in $\mathrm{H}_{2} / \mathrm{O}_{2}$ fuel cell and $0.28 \mathrm{~W} / \mathrm{cm}^{2}$ in $\mathrm{H}_{2}$ /air fuel cell [81]. Besides transition metals such as $\mathrm{Fe}$, $\mathrm{Co}$ and $\mathrm{Mn}$ that are widely used as active component in M-N-C catalyst, a Fenton inactive tin/nitrogen-doped carbon fuel cell cathode catalyst has been reported to exhibit a 40-50\% higher current density than Fe-N-C type catalyst at cell voltages below $0.7 \mathrm{~V}$ by Luo et 
al [82]. It is worth noting that a hybrid catalyst composed of both Fe-N-C type NPMC and $\mathrm{Pt} / \mathrm{C}$ is found to exhibit enhanced stability and activity in PEMFCs (Table 1).

Table 1. The area specific ORR activity and mass activity of selected catalysts measured at $0.9 \mathrm{~V}_{\mathrm{RHE}}$.

\begin{tabular}{|c|c|c|c|}
\hline Catalyst & $\begin{array}{l}\text { Surface Activity/ } \\
\mathrm{mA} / \mathrm{cm}^{2}\end{array}$ & $\begin{array}{c}\text { Mass Activity/ } \\
\text { A/mg }\end{array}$ & Ref. \\
\hline commercial Pt/C & 0.23 & 0.15 & [83] \\
\hline DoE 2020 target & - & 0.44 & [83] \\
\hline $\mathrm{Pt}_{3} \mathrm{Ni}\{111\}$ & 18 & - & [84] \\
\hline $\mathrm{Pt}_{1.5} \mathrm{Ni}$ & 3.99 & 1.96 & [85] \\
\hline $\mathrm{Pt}_{x} \mathrm{Gd}$ alloy & - & 3.6 & [86] \\
\hline $\mathrm{Pt}_{3} \mathrm{Y}$ thin layer & 13.4 & 3.5 & [87] \\
\hline $\mathrm{Pt} / \mathrm{NiO}$ core-shell nanowires & 11.5 & 13.6 & [88] \\
\hline PtFe N-doped carbon shell & - & 1.6 & [89] \\
\hline $\mathrm{Pt}_{2} \mathrm{CuNi}$ octahedrons & - & 2.35 & [89] \\
\hline Pt-Ni octahedrons & - & 3.3 & [90] \\
\hline $\mathrm{Au}-7.7 \mathrm{~nm} @ \mathrm{Ni}_{2} \mathrm{Pt}_{2} / \mathrm{C}$ & 1.6 & 0.496 & [91] \\
\hline $\mathrm{Ru} @ \mathrm{Pt} / \mathrm{C}$ & 0.7 & 0.5 & [92] \\
\hline NCs/CNTs (Pt loading 10\%) & 0.194 & 0.167 & [93] \\
\hline Fe-containing nanocrystals & 6.18 & - & [94] \\
\hline PtFe nanowires & - & 3.4 & [95] \\
\hline $\mathrm{TiCoN}_{\mathrm{x}} / \mathrm{N}-\mathrm{rGO}$ & 2.51 & - & [96] \\
\hline magnet core-shell $\mathrm{L}_{10} \mathrm{CoPt} / \mathrm{Pt}$ & - & 2.26 & [97] \\
\hline tetrahedral $\mathrm{YBaCo}_{4} \mathrm{O}_{7.3}$ & 2.76 & - & [98] \\
\hline $\mathrm{Fe}-\mathrm{N}-\mathrm{C}+\mathrm{Pt} / \mathrm{C}$ & - & 0.22 & [99] \\
\hline
\end{tabular}

The performance comparison with $\mathrm{Pt} / \mathrm{C}$ has been reported by Proietti et al. [100]. The maximum performance of $0.91 \mathrm{~W} / \mathrm{cm}^{2}$ represents approximately $75 \%$ of the performance achieved with $\mathrm{Pt} / \mathrm{C}$ catalyst in the same experimental set-up.

\section{Perspectives on Stability of PGM Catalyst and NPMC}

The PGM based cathode catalyst is the technically feasible option for a commercial PEMFC stack. The durability becomes an issue only when the Pt loading is decreased in the cathode. The stability of catalyst is further strongly affected by conditions in operating PEMFC, see Figure 1. These conditions include (a) excess water flooding in electrode, (b) oxygen permeability through ionomer phase in catalytic layer, (c) pressure of the reactants, (d) start-up and shut-down conditions, (e) fuel deficiency at high performance conditions [101]. The continuous potential fluctuations experienced by the Pt nanoparticles in the cathode triggers onset of $\mathrm{Pt}$ dissolution and carbon corrosion. The electrochemical active surface area (ECSA) of Pt nanoparticles decreases over long-term operation due to collapse of the carbon support and subsequent aggregation of Pt nanoparticles and dissolution of base metals in the case of Pt alloy nanoparticles. The base metal dissolution, difficulty in maintaining the geometry of particles makes the use of shape-controlled $\mathrm{Pt}$ alloy catalyst extremely difficult. Therefore, it is necessary to optimize the activity and durability of catalyst particles recognizing the existence of trade-offs. Several approaches such as doping rhodium or nitrogen have been effective to reduce the dissolution of base metal Ni from the core in the case of PtNi nanoparticles. Preparation of Pt-Ni catalyst covered with Pt skin layer has also been reported to improve durability [102]. Stamenkovic et al. proposed that the utilization of a gold $(\mathrm{Au})$ underlayer promotes ordering of $\mathrm{Pt}$ surface atoms towards a (111) structure, whereas Au on the surface selectively protects low-coordinated Pt sites [103]. This mitigation strategy was applied towards $3 \mathrm{~nm} \mathrm{Pt}_{3} \mathrm{Au} / \mathrm{C}$ nanoparticles and have shown the elimination of $\mathrm{Pt}$ dissolution in the liquid electrolyte in addition to 30 -fold durability improvement versus $3 \mathrm{~nm} \mathrm{Pt} / \mathrm{C}$ over an extended potential range up to $1.2 \mathrm{~V}$. However, these materials have to be tested at the MEA level and the improvement in durability must be demonstrated at the same level reported in liquid electrolytes. 
The PGM-free NPMC is still under its earlier development stage, some M-N-C type electrocatalysts may demonstrate the similar ORR activity as Pt under rotating disc electrode (RDE) conditions but none of them could reach a similar PEMFC performance. The durability issues associated with NPMCs, specifically M-N-C, has not yet been clearly identified due to the efforts so far devoted mostly to the identification of the structure of active sites present in these types of composite catalysts. In an attempt to solve the activity-stability trade-off riddle associated with Fe-N-C catalyst, Jaouen et al. have identified durable and non-durable $\mathrm{FeN}_{\mathrm{x}}$ sites in Fe-N-C catalyst materials and described the two distinct degradation pathways. They show that $\mathrm{Fe}-\mathrm{N}-\mathrm{C}$ catalysts initially comprising two distinct FeN sites, namely, high-spin S1 site and the low- or intermediate-spin S2 site, both assigned to $\mathrm{FeN}_{4}$ moieties but embedded in different ways in the carbon matrix [104]. Among these two sites, S1 is not durable in operating PEM fuel cells, quickly transforming to ferric oxides. In contrast, $\mathrm{S} 2$ is shown to be more durable, with no measurable decrease of the number of active sites after $50 \mathrm{~h}$ operation at $0.5 \mathrm{~V}$. The authors advocate further studies with a focus on increasing the site density of S2 sites and/or stabilizing S1 in acidic and oxygenated environments. There is still some distance to cover to make the Fe-N-C material desirable for direct application and continuous testing in PEM fuel cell stacks.

\section{Conclusions}

In recent years, significant progress in the development of the ORR catalyst has been made. In the field of theoretical research, a deep understanding of ORR has been achieved. From the point of view of experimental research, an immense effort has been spent in catalyst design, catalyst support development and tuning of electrochemical activity.

In terms of fuel cells commercialization, there is a desperate need for efficient ORR catalyst. The main obstacles are the activity, stability and the cost of developed materials. Nowadays, the state-of-the-art catalyst is based on platinum particles dispersed on the carbon support. In last decades, the platinum loading of the developed catalysts has been significantly decreased. On the other hand, the remarkable activities of low-loading catalysts suffer from voltage cycling and other real-life conditions.

The catalysts performance and stability can be improved by adjusting parameters of the operating fuel cell, i.e., humidity, temperature and flow of reactants. The future research should be focused on optimization of these parameters to overcome the stability issues. The properties of the catalysts can be also improved by homogenous deposition of the catalytic material within the MEA or by optimizing the catalyst loading. Furthermore, by employing advanced support materials like carbon nanotubes, graphene or carbon nanowalls, the durability of the catalyst can be increased [105].

The outstanding activity of core-shell nanoparticles, nanowires or nanorods has been demonstrated by many research groups. At the current stage for those well-shaped and core-shell Pt nanoparticles, the major challenge still concentrates on how to successfully transfer their high RDE activity to PEMFC performance.

In the case of further improvement of ORR catalyst activity, stability and subsequent mass production, the applications such as hydrogen fuel cells or metal-air batteries would be viable options for the shift to sustainable and environmentally friendly renewable energy technologies.

Author Contributions: Conceptualization, M.T.; investigation, F.G., Z.G.; writing-original draft preparation, M.T.; writing—review and editing, M.T., F.G., Z.G., J.S. All authors have read and agreed to the published version of the manuscript.

Funding: The result was developed within the CENTEM project, reg. no. CZ.1.05/2.1.00/03.0088, cofunded by the ERDF as part of the Ministry of Education, Youth and Sports OP RDI programme and, in the follow-up sustainability stage, supported through CENTEM PLUS (LO1402) by financial means from the Ministry of Education, Youth and Sports under the National Sustainability Programme I.

Institutional Review Board Statement: Not applicable.

Informed Consent Statement: Not applicable. 
Data Availability Statement: Data available in a publicly accessible repository.

Conflicts of Interest: The authors declare no conflict of interest. The funders had no role in the design of the study; in the collection, analyses or interpretation of data; in the writing of the manuscript or in the decision to publish the results.

$\begin{array}{ll}\text { Abbreviations } \\ \text { The following abbreviations are used in this man } \\ \text { PEMFC } & \text { Proton exchange membrane fuel cells } \\ \text { PGM } & \text { Platinum group metals } \\ \text { ORR } & \text { Oxygen reduction reaction } \\ \text { HOR } & \text { Hydrogen oxidation reaction } \\ \text { GDL } & \text { Gas diffusion layer } \\ \text { NHE } & \text { Normal Hydrogen Electrode } \\ \text { ICE } & \text { Internal combustion engines } \\ \text { MEA } & \text { Membrane electrode assembly } \\ \text { BoL } & \text { Beginning of Life } \\ \text { NPMC } & \text { Non-precious metal catalyst } \\ \text { DoE } & \text { Department of Energy (USA) } \\ \text { RHE } & \text { Reversible Hydrogen Electrode } \\ \text { CNT } & \text { Carbon nanotubes } \\ \text { NC } & \text { Nanocluster }\end{array}$

\section{References}

1. He, W.; King, M.; Luo, X.; Dooner, M.; Li, D.; Wang, J. Technologies and economics of electric energy storages in power systems: Review and perspective. Adv. Appl. Energy 2021, 4, 100060. [CrossRef]

2. Zhang, H.; Sun, C. Cost-effective iron-based aqueous redox flow batteries for large-scale energy storage application: A review. J. Power Sources 2021, 493, 229445. [CrossRef]

3. $\mathrm{Wu}, \mathrm{F}$; Maier, J.; Yan, Y. Guidelines and trends for next-generation rechargeable lithium and lithium-ion batteries. Chem. Soc. Rev. 2020, 49, 1569-1614. [CrossRef]

4. Olabi, A.G.; Onumaegbu, C.; Wilberforce, T.; Ramadan, M.; Abdelkareem, M.A.; Al-Alami, A.H. Critical review of energy storage systems. Energy 2021, 214, 118987. [CrossRef]

5. Irfan, M.; Abas, N.; Saleem, M.S. Thermal performance analysis of net zero energy home for sub zero temperature areas. Case Stud. 2018, 12, 789-796. [CrossRef]

6. Khatib, F.N. Material degradation of components in polymer electrolyte membrane (PEM) electrolytic cell and mitigation mechanisms: A review. Renew. Sust. Energ. Rev. 2019, 111, 1-14. [CrossRef]

7. Sharaf, O.Z.; Orhan, M.F. An Overview of Fuel Cell Technology: Fundamentals and Applications. Renew. Sustain. Energy Rev. 2014, 32, 810-853. [CrossRef]

8. Marsik, F.; Weigand, B.; Tomas, M.; Tucek, O.; Novotny, P. On the Efficiency of Electrochemical Devices from the Perspective of Endoreversible Thermodynamics. J. Non-Equilib. Thermodyn. 2019, 44, 425-437. [CrossRef]

9. Staffell, I.; Scamman, D.; Abad, A.V.; Balcombe, P.; Dodds, P.E.; Ekins, P.; Shah, N.; Ward, K.R. The Role of Hydrogen and Fuel Cells in the Global Energy System. Energy Environ. Sci. 2019, 12, 463-491. [CrossRef]

10. Pollet, B.G.; Kocha, S.S.; Staffell, I. Current Status of Automotive Fuel Cells for Sustainable Transport. Curr. Opin. Electrochem. 2019, 16, 90-95. [CrossRef]

11. Sazali, N.; Wan Salleh, W.N.; Jamaludin, A.S.; Mhd Razali, M.N. New Perspectives on Fuel Cell Technology: A Brief Review. Membranes 2020, 10, 99. [CrossRef] [PubMed]

12. Zhang, J.; Aili, D.; Lu, S.; Li, Q.; Jiang, S.P. Advancement toward Polymer Electrolyte Membrane Fuel Cells at Elevated Temperatures. Research 2020, 2020, 9089405. [CrossRef] [PubMed]

13. Borup, R.L.; Kusoglu, A.; Neyerlin, K.C.; Mukundan, R.; Ahluwalia, R.K.; Cullen, D.A.; More, K.L.; Weber, A.Z.; Myers, D.J. Recent Developments in Catalyst-related PEM Fuel Cell Durability. Curr. Opin. Electrochem. 2020, 21, 192-200. [CrossRef]

14. Wang, X.; Li, Z.; Qu, Y.; Yuan, T.; Wang, W.; Wu, Y.; Li, Y. Review of Metal Catalysts for Oxygen Reduction Reaction: From Nanoscale Engineering to Atomic Design. Chem 2019, 5, 1486-1511. [CrossRef]

15. Sui, S.; Wang, X.; Zhou, X.; Su, Y.; Riffat, S.; Liu, C.J. A comprehensive review of Pt electrocatalysts for the oxygen reduction reaction: Nanostructure, activity, mechanism and carbon support in PEM fuel cells. J. Mater. Chem. A 2017, 5, 1808-1825. [CrossRef]

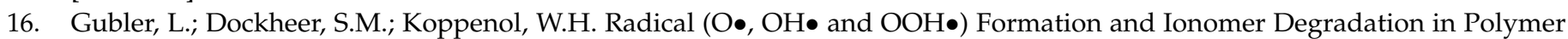
Electrolyte Fuel Cells. J. Electrochem. Soc. 2011, 158, B755-B769. [CrossRef] 
17. Li, Y.; Li, Q.; Wang, H.; Zhang, L.; Wilkinson, D.P.; Zhang, J. Recent Progresses in Oxygen Reduction Reaction Electrocatalysts for Electrochemical Energy Applications. Electrochem. Energy Rev. 2019, 2, 518-538. [CrossRef]

18. Pivovar, B. Catalysts for Fuel Cell Transportation and Hydrogen Related Uses. Nat. Catal. 2019, 2, 562-565. [CrossRef]

19. David, M.; Lyth, S.M.; Lindner, R.; Harrington, G.F. Future-Proofing Fuel Cells, Critical Raw Material Governance in Sustainable Energy; Palgrave Macmillan: London, UK, 2021; ISBN 978-3-030-76806-5.

20. Ren, X.; Lv, Q.; Liu, L.; Liu, B.; Wang, Y.; Liu, A.; Wu, G. Current Progress of Pt and Pt-based Electrocatalysts Used for Fuel Cells. Sustain. Energy Fuels 2020, 4, 15-30. [CrossRef]

21. Wang, Y.; Wu, H.; Stoddart, J.F. Molecular Triangles: A New Class of Macrocycles. Acc. Chem. Res. 2021, 54, 2027-2039. [CrossRef]

22. Greeley, J.; Mavrikakis, M. Alloy Catalysts Designed from First Principles. Nat. Mater. 2004, 3, 810-815. [CrossRef]

23. Seselj, N.; Engelbrekt, C.; Zhang, J. Graphene-supported Platinum Catalysts for Fuel Cells. Sci. Bull. 2015, 60, 864-876. [CrossRef]

24. Yang, X.F.; Wang, A.; Qiao, B.; Li, J.; Liu, J.; Zhang, T. Single-Atom Catalysts: A New Frontierin Heterogeneous Catalysis. Acc. Chem. Res. 2013, 46, 1740-1748. [CrossRef] [PubMed]

25. Yu, T.; Kim, D.Y.; Zhang, H.; Xia, Y. Platinum Concave Nanocubes with High-Index Facets and Their Enhanced Activity for Oxygen Reduction Reaction. Angew. Chem. Int. Ed. 2011, 123, 2825-2829. [CrossRef]

26. Zhang, J.; Zhang, L.; Cui, Z. Strategies to enhance the electrochemical performances of Pt-based intermetallic catalysts. Chem. Commun. 2021, 57, 11-26. [CrossRef] [PubMed]

27. Rößner, L.; Armbrüster, M. Electrochemical Energy Conversion on Intermetallic Compounds: A Review. ACS Catal. 2019, 9, 2018-2062. [CrossRef]

28. Sievers, G.W.; Jensen, A.W.; Quinson, J.; Zana, A.; Bizzotto, F.; Oezaslan, M.; Dworzak, A.; Kirkensgaard, J.J.; Smitshuysen, T.E.; Kadkhodazadeh, S.; et al. Self-supported Pt-CoO Networks Combining High Specific Activity with High Surface Area for Oxygen Reduction. Nat. Mater. 2021, 20, 208-213. [CrossRef]

29. Ioroi, T.; Yasuda, K. Platinum-Iridium Alloys as Oxygen Reduction Electrocatalystsfor Polymer Electrolyte Fuel Cells. J. Electrochem. Soc. 2005, 152, A1917-A1924. [CrossRef]

30. Ganesan, A.; Narayanasamy, M. Ultra low Loading of Platinum in Proton Exchange Membrane based Fuel Cells: A Brief Review. Mater. Renew. Sustain. Energy 2019, 8, 18. [CrossRef]

31. Dai, Y.; Liu, Y.; Chen, S. Pt-W Bimetallic Alloys as CO-tolerant PEMFC Anode Catalysts. Electrochim. Acta 2013, 89, 744-748. [CrossRef]

32. Cui, Y.; Wu, Y.; Wang, Z.; Yao, X.; Wei, Y.; Kang, Y.; Du, H.; Li, J.; Gan, L. Mitigating Metal Dissolution and Redeposition of Pt-Co Catalysts in PEM Fuel Cells: Impacts of Structural Ordering and Particle Size. J. Electrochem. Soc. 2020, 167, 064520. [CrossRef]

33. Gasteiger, H.A.; Markovic, N.M. Just a Dream-Or Future Reality? Science 2009, 324, 48-49. [CrossRef]

34. Luna, A.C.; Bonesi, A.; Triaca, W.E.; Di Blasi, A.; Stassi, A.; Baglio, V.; Antonucci, V.; Aricò, A.S. Investigation of a Pt-Fe/C Catalyst for Oxygen Reduction Reaction in Direct Ethanol Fuel Cells. J. Nanopart. Res. 2010, 12, 357-365. [CrossRef]

35. Tian, X.; Zhao, X.; Su, Y.Q.; Wang, L.; Wang, H.; Dang, D.; Chi, B.; Liu, H.; Hensen, E.J.; Lou, X.W.D.; et al. Engineering Bunched Pt-Ni Alloy Nanocages for Efficient Oxygen Reduction in Practical Fuel Cells. Science 2019, 366, 850-856. [CrossRef] [PubMed]

36. Zignani, S.C.; Baglio, V.; Sebastián, D.; Saccà, A.; Gatto, I.; Aricò, A.S. Towards Highly Performing and Stable PtNi Catalysts in Polymer Electrolyte Fuel Cells for Automotive Application. Materials 2017, 10, 317. [CrossRef] [PubMed]

37. Nie, Y.; Li, L.; Wei, Z. Recent Advancements in Pt and Pt-free Catalysts for Oxygen Reduction Reaction. Chem. Soc. Rev. 2015, 44, 2168-2201. [CrossRef]

38. Chung, D.Y.; Kim, H.I.; Chung, Y.H.; Lee, M.J.; Yoo, S.J.; Bokare, A.D.; Choi, W.; Sung, Y.E. Inhibition of CO Poisoning on Pt Catalyst Coupled with the Reduction of Toxic Hexavalent Chromium in a Dual-Functional Fuel Cell. Sci. Rep. 2014, 4, 7450. [CrossRef] [PubMed]

39. Min, J.; Jeffery, A.A.; Kim, Y.; Jung, N. Electrochemical Analysis for Demonstrating CO Tolerance of Catalysts in Polymer Electrolyte Membrane Fuel Cells. Nanomaterials 2019, 9, 1425. [CrossRef] [PubMed]

40. Vignarooban, K.; Lin, J.; Arvay, A.; Kolli, S.; Kruusenberg, I.; Tammeveski, K.; Munukutla, L.; Kannan, A.M. Nano-electrocatalyst Materials for Low Temperature Fuel Cells: A Review. Chin. J. Catal. 2015, 36, 458-472. [CrossRef]

41. Walker, J.S.; Rees, N.V.; Mendes, P.M. Progress Towards the Ideal Core@shell Nanoparticle for Fuel Cell Electrocatalysis. J. Exp. Nanosci. 2018, 13, 258-271. [CrossRef]

42. Kuttiyiel, K.A.; Choi, Y.; Hwang, S.M.; Park, G.G.; Yang, T.H.; Su, D.; Sasaki, K.; Liu, P.; Adzic, R.R. Enhancement of the Oxygen Reduction on Nitride Stabilized pt-M (M=Fe, Co and Ni) Core-shell Nanoparticle Electrocatalysts. Nano Energy 2015, 13, 442-449. [CrossRef]

43. Santhosh Kumar, K.; Bhooshan Kumar, V.; Paik, P. Recent Advancement in Functional Core-Shell Nanoparticles of Polymers: Synthesis, Physical Properties and Applications in Medical Biotechnology. J. Nanopart. 2013, 2013, 672059.

44. Yurukcu, M.; Badradeen, E.; Bilnoski, S.; Yurtsever, F.; Begum, M. The Effect of the Core/shell Nanostructure Arrays on PEM Fuel Cells: A Short Review. Mater. Sci. Eng. 2018, 2, 58-64. [CrossRef]

45. Xu, Y.; Ruban, A.V.; Mavrikakis, M. Adsorption and Dissociation of $\mathrm{O}_{2}$ on Pt-Co and Pt-Fe Alloys. J. Am. Chem. Soc. 2004, 126, 4717-4725. [CrossRef] [PubMed]

46. Long, N.V.; Yang, Y.; Thi, C.M.; Van Minh, N.; Cao, Y.; Nogami, M. The Development of Mixture, Alloy and Core-shell Nanocatalysts with Nanomaterial Supports for Energy Conversion in Low-temperature Fuel Cells. Nano Energy 2013, 2, 636-676. [CrossRef] 
47. Hwang, S.J.; Yoo, S.J.; Shin, J.; Cho, Y.H.; Jang, J.H.; Cho, E.; Sung, Y.E.; Nam, S.W.; Lim, T.H.; Lee, S.C.; et al. Supported Core@Shell Electrocatalysts for Fuel Cells: Close Encounter with Reality. Sci. Rep. 2013, 3, 1309. [CrossRef] [PubMed]

48. Karuppannan, M.; Kim, Y.; Gok, S.; Lee, E.; Hwang, J.Y.; Jang, J.H.; Cho, Y.H.; Lim, T.; Sung, Y.E.; Kwon, O.J. A Highly Durable Carbon-nanofiber-supported Pt-C Core-shell Cathode Catalyst for Ultra-low Pt Loading Proton Exchange Membrane Fuel Cells: Facile Carbon Encapsulation. Energy Environ. Sci. 2019, 12, 2820-2829. [CrossRef]

49. Oezaslan, M.; Hasché, F.; Strasser, P. Pt-Based Core-Shell Catalyst Architectures for Oxygen Fuel Cell Electrodes. J. Phys. Chem. Lett. 2013, 4, 3273-3291. [CrossRef]

50. Wang, R.; Wang, H.; Luo, F.; Liao, S. Core-Shell-Structured Low-Platinum Electrocatalysts for Fuel Cell Applications. Electrochem. Energy Rev. 2018, 1, 324-387. [CrossRef]

51. Gawande, M.B.; Goswami, A.; Asefa, T.; Guo, H.; Biradar, A.V.; Peng, D.L.; Zboril, R.; Varma, R.S. Core-shell Nanoparticles: Synthesis and Applications in Catalysis and Electrocatalysis. Chem. Soc. Rev. 2015, 44, 7540-7590. [CrossRef]

52. Tao, L.; Huang, B.; Jin, F.; Yang, Y.; Luo, M.; Sun, M.; Liu, Q.; Gao, F.; Guo, S. Atomic PdAu Interlayer Sandwiched into Pd/Pt Core/Shell Nanowires Achieves Superstable Oxygen Reduction Catalysis. ACS Nano 2020, 14, 11570-11578. [CrossRef] [PubMed]

53. Hu, J.; Wu, L.; Kuttiyiel, K.A.; Goodman, K.R.; Zhang, C.; Zhu, Y.; Vukmirovic, M.B.; White, M.G.; Sasaki, K.; Adzic, R.R. Increasing Stability and Activity of Core-shell Catalysts by Preferential Segregation of Oxide on Edges and Vertexes: Oxygen Reduction on Ti-Au@Pt/C. J. Am. Chem. Soc. 2016, 138, 9294-9300. [CrossRef]

54. Miyazaki, K.; Mori, H. Origin of High Oxygen Reduction Reaction Activity of $\mathrm{Pt}_{12}$ and Strategy to Obtain Better Catalyst Using Sub-nanosized Pt-alloy Clusters. Sci. Rep. 2017, 7, 45381. [CrossRef]

55. Tian, N.; Lu, B.A.; Yang, X.D.; Huang, R.; Jiang, Y.X.; Zhou, Z.Y.; Sun, S.G. Rational Design and Synthesis of Low Temperature Fuel Cell Electrocatalysts. Electrochem. Energy Rev. 2018, 1, 54-83. [CrossRef]

56. Wang, J.; Li, B.; Yersak, T.; Yang, D.; Xiao, Q.; Zhang, J.; Zhang, C. Recent Advances in Pt-based Octahedral Nanocrystals as High Performance Fuel Cell Catalysts. J. Mater. Chem. A 2016, 4, 11559-11581. [CrossRef]

57. Huang, X.; Zhu, E.; Chen, Y.; Li, Y.; Chiu, C.Y.; Xu, Y.; Lin, Z.; Duan, X.; Huang, Y. A Facile Strategy to Pt ${ }_{3} \mathrm{Ni}_{\mathrm{Nanocrystals} \mathrm{with}}$ Highly Porous Features as an Enhanced Oxygen Reduction Reaction Catalyst. Adv. Mater. 2013, 25, 2974-2979. [CrossRef]

58. Choi, S.I.; Xie, S.; Shao, M.; Odell, J.H.; Lu, N.; Peng, H.C.; Protsailo, L.; Guerrero, S.; Park, J.; Xia, X.; et al. Synthesis and Characterization of 9-nm Pt-Ni Octahedra with a Record High Activity of $3.3 \mathrm{~A} / \mathrm{mg}_{\mathrm{Pt}}$ for the Oxygen Reduction Reaction. Nano Lett. 2013, 13, 3420-3425. [CrossRef]

59. Wang, Y.J.; Long, W.; Wang, L.; Yuan, R.; Ignaszak, A.; Fang, B.; Wilkinson, D.P. Unlocking the Door to Highly Active ORR Catalysts for PEMFC Applications: Polyhedron-engineered Pt-based Nanocrystals. Energy Environ. Sci. 2018, 11, 258-275. [CrossRef]

60. Zhu, J.; Elnabawy, A.O.; Lyu, Z.; Xie, M.; Murray, E.A.; Chen, Z.; Jin, W.; Mavrikakis, M.; Xia, Y. Facet-controlled Pt-Ir Nanocrystals with Substantially Enhanced Activity and Durability Towards Oxygen Reduction. Mater. Today 2020, 35, 69-77. [CrossRef]

61. Lori, O.; Elbaz, L. Advances in Ceramic Supports for Polymer Electrolyte Fuel Cells. Catalysts 2015, 5, 1445-1464. [CrossRef]

62. Chen, M.; Hwang, S.; Li, J.; Karakalos, S.; Chen, K.; He, Y.; Mukherjee, S.; Su, D.; Wu, G. Pt alloy nanoparticles decorated on large-size nitrogen-doped graphene tubes for highly stable oxygen-reduction catalysts. Nanoscale 2018, 10, 17318-17326. [CrossRef]

63. Yang, X.D.; Chen, C.; Zhou, Z.Y.; Sun, S.G. Advances in Active Site Structure of Carbon-Based Non-Precious Metal Catalysts for Oxygen Reduction Reaction. Acta Phys. Chim. Sin. 2019, 35, 472-485. [CrossRef]

64. Ren, G.; Gao, L.; Teng, C.; Li, Y.; Yang, H.; Shui, J.; Lu, X.; Zhu, Y.; Dai, L. Ancient Chemistry “Pharaoh's Snakes” for Efficient Fe-/N-Doped Carbon Electrocatalysts. ACS Appl. Mater. Interfaces 2018, 10, 10778-10785. [CrossRef] [PubMed]

65. Bau, V.M.; Bo, X.; Guo, L. Nitrogen-doped Cobalt Nanoparticles/nitrogen-doped Plate-like Ordered Mesoporous Carbons Composites as Noble-metal Free Electrocatalysts for Oxygen Reduction Reaction. J. Energy Chem. 2017, 26, 63-71. [CrossRef]

66. Wang, L.; Wan, X.; Liu, S.; Xu, L.; Shui, J. Fe-N-C Catalysts for PEMFC: Progress Towards the Commercial Application under DOE Reference. J. Energy Chem. 2019, 39, 77-87. [CrossRef]

67. Thompson, S.T.; James, B.D.; Huya-Kouadio, J.M.; Houchins, C.; DeSantis, D.A.; Ahluwalia, R.; Wilson, A.R.; Kleen, G.; Papageorgopoulos, D. Direct Hydrogen Fuel Cell Electric Vehicle Cost Analysis: System and High-volume Manufacturing Description, Validation and Outlook. J. Power Sources 2018, 399, 304-313. [CrossRef]

68. James, B.D.; Huya-Kouadio, J.M.; Houchins, C. Mass Production Cost Estimation of Direct $\mathrm{H}_{2}$ PEM Fuel Cell Systems for Transportation Applications: 2015 Update. Report, US Department of Energy, Strategic Analysis. 2015. Available online: https:/ / www.energy.gov/sites / prod/files/2016/11/f34/fcto_sa_2015_pemfc_transportation_cost_analysis.pdf (accessed on 20 October 2021).

69. Banham, D.; Ye, S. Current Status and Future Development of Catalyst Materials and Catalyst Layers for Proton Exchange Membrane Fuel Cells: An Industrial Perspective. ACS Energy Lett. 2017, 2, 629-638. [CrossRef]

70. Zagal, J.H.; Koper, M.T.M. Reactivity Descriptors for the Activity of Molecular $\mathrm{MN}_{4}$ Catalysts for the Oxygen Reduction Reaction. Angew. Chem. Int. Edit. 2016, 55, 14510-1452. [CrossRef]

71. Sgarbi, R.; Kumar, K.; Jaouen, F.; Zitolo, A.; Ticianelli, E.A.; Maillard, F. Oxygen Reduction Reaction Mechanism and Kinetics on $\mathrm{M}-\mathrm{N}_{x} \mathrm{C}_{y}$ and $\mathrm{M} @ \mathrm{~N}-\mathrm{C}$ Active Sites Present in Model M-N-C Catalysts under Alkaline and Acidic Conditions. J. Solid State Chem. 2021, 25, 45-56 [CrossRef] 
72. Song, M.; Song, Y.; Sha, W.; Xu, B.; Guo, J.; Wu, Y. Recent Advances in Non-Precious Transition Metal/Nitrogen-doped Carbon for Oxygen Reduction Electrocatalysts in PEMFCs. Catalysts 2020, 10, 141. [CrossRef]

73. Yamazaki, S. Metalloporphyrins and Related Metallomacrocycles as Electrocatalysts for Use in Polymer Electrolyte Fuel Cells and Water Electrolyzers. Coordin. Chem. Rev. 2018, 373, 148-166. [CrossRef]

74. Othman, R.; Dicks, A.L.; Zhu, Z. Non Precious Metal Catalysts for the PEM Fuel Cell Cathode. Int. J. Hydrog. Energy 2012, 37, 357-372. [CrossRef]

75. Chen, Z.; Higgins, D.; Yu, A.; Zhang, L.; Zhang, J. A Review on Non-precious Metal Electrocatalysts for PEM Fuel Cells. Energy Environ. Sci. 2011, 4, 3167-3192. [CrossRef]

76. Banham, D.; Kishimoto, T.; Zhou, Y.; Sato, T.; Bai, K.; Ozaki, J.I.; Imashiro, Y.; Ye, S. Critical Advancements in Achieving High Power and Stable Nonprecious Metal Catalyst-based MEAs for Real-world Proton Exchange Membrane Fuel Cell Applications. Sci. Adv. 2018, 4, eaar7180. [CrossRef]

77. Liu, Q.; Liu, X.; Zheng, L.; Shui, J. The Solid-Phase Synthesis of an Fe-N-C Electrocatalyst for High-Power Proton-Exchange Membrane Fuel Cells. Angew. Chem. Int. Edit. 2018, 57, 1204-1208. [CrossRef] [PubMed]

78. Liang, G.; Huang, J.; Li, J.; Wu, Y.; Huang, G.; Jin, Y.Q.; Zeng, H.; Zhang, H.; Chen, J.; Jin, Y.; et al. Improving the Catalytic Performance of Co/N/C Catalyst for Oxygen Reduction Reaction by Alloying with Fe. J. Electrochem. Soc. 2020, 167, 104502. [CrossRef]

79. Xia, D.; Liu, S.; Wang, Z.; Chen, G.; Zhang, L.; Zhang, L.; Hui, S.R.; Zhang, J. Methanol-tolerant MoN Electrocatalyst Synthesized Through Heat Treatment of Molybdenum Tetraphenylporphyrin for Four-electron Oxygen Reduction Reaction. J. Power Sources 2008, 177, 296-302. [CrossRef]

80. Li, J.; Chen, M.; Cullen, D.A.; Hwang, S.; Wang, M.; Li, B.; Liu, K.; Karakalos, S.; Lucero, M.; Zhang, H.; et al. Atomically dispersed manganese catalysts for oxygen reduction in proton-exchange membrane fuel cells. Nat. Catal. 2018, 1, 935-945. [CrossRef]

81. Wang, X.X.; Cullen, D.A.; Pan, Y.T.; Hwang, S.; Wang, M.; Feng, Z.; Wang, J.; Engelhard, M.H.; Zhang, H.; He, Y.; et al. NitrogenCoordinated Single Cobalt Atom Catalysts for Oxygen Reduction in Proton Exchange Membrane Fuel Cells. Adv. Mater. 2018, 30, 1706758. [CrossRef] [PubMed]

82. Luo, F.; Roy, A.; Silvioli, L.; Cullen, D.A.; Zitolo, A.; Sougrati, M.T.; Oguz, I.C.; Mineva, T.; Teschner, D.; Wagner, S.; et al. P-Block Single-Met. Tin/nitrogen-Doped Carbon Fuel Cell Cathode Catal. Oxyg. Reduct. Reaction. Nat. Mater. 2020, 19, $1215-1223$. [CrossRef]

83. Zhang, C.; Shen, X.; Pan, Y.; Peng, Z. A Review of Pt-based Electrocatalysts for Oxygen Reduction Reaction. Front. Energy 2017, 11, 268-285. [CrossRef]

84. Stamenkovic, V.R.; Fowler, B.; Mun, B.S.; Wang, G.; Ross, P.N.; Lucas, C.A.; Marković, N.M. Improved Oxygen Reduction Activity on $\mathrm{Pt}_{3} \mathrm{Ni}(111)$ via Increased Surface Site Availability. Science 2007, 315, 493-497. [CrossRef]

85. Zhang, C.; Hwang, S.Y.; Trout, A.; Peng, Z. Solid-State Chemistry-Enabled Scalable Production of Octahedral Pt-Ni Alloy Electrocatalyst for Oxygen Reduction Reaction. J. Am. Chem. Soc. 2014, 136, 7805-7808. [CrossRef]

86. Escudero-Escribano, M.; Malacrida, P.; Hansen, M.H.; Vej-Hansen, U.G.; Velázquez-Palenzuela, A.; Tripkovic, V.; Schiøtz, J.; Rossmeisl, J.; Stephens, I.E.; Chorkendorff, I. Tuning the Activity of Pt Alloy Electrocatalysts by Means of the Lanthanide Contraction. Science 2016, 352, 73-76. [CrossRef]

87. Lindahl, N.; Zamburlini, E.; Feng, L.; Grönbeck, H.; Escudero-Escribano, M.; Stephens, I.E.; Chorkendorff, I.; Langhammer, C.; Wickman, B. High Specific and Mass Activity for the Oxygen Reduction Reaction for Thin Film Catalysts of Sputtered Pt $\mathrm{P}_{3} \mathrm{Y}$. Adv. Mater. Interfaces 2017, 4, 1700311. [CrossRef]

88. Li, M.; Zhao, Z.; Cheng, T.; Fortunelli, A.; Chen, C.Y.; Yu, R.; Zhang, Q.; Gu, L.; Merinov, B.V.; Lin, Z.; et al. Ultrafine Jagged Platinum Nanowires Enable Ultrahigh Mass Activity for the Oxygen Reduction Reaction. Science 2016, 354, 1414-1419. [CrossRef]

89. Chung, D.Y.; Jun, S.W.; Yoon, G.; Kwon, S.G.; Shin, D.Y.; Seo, P.; Yoo, J.M.; Shin, H.; Chung, Y.H.; Kim, H.; et al. Highly Durable and Active PtFe Nanocatalyst for Electrochemical Oxygen Reduction Reaction. J. Am. Chem. Soc. 2016, 137, 15478-15485. [CrossRef] [PubMed]

90. Lv, H.; Li, D.; Strmcnik, D.; Paulikas, A.P.; Markovic, N.M.; Stamenkovic, V.R. Recent Advances in the Design of Tailored Nanomaterials for Efficient Oxygen Reduction Reaction. Nano Energy 2016, 29, 149-165. [CrossRef]

91. Zhang, M.; Miao, S.; Xu, B.Q. Core@Shell Nanostructured Au - d@Ni $\mathrm{NPt}_{m}$ for Electrochemical Oxygen Reduction Reaction: Effect of the Core Size and Shell Thickness. Catal. Sci. Technol. 2019, 9, 4668-4677. [CrossRef]

92. Jackson, A.; Strickler, A.; Higgins, D.; Jaramillo, T.F. Engineering Ru@Pt Core-Shell Catalysts for Enhanced Electrochemical Oxygen Reduction Mass Activity and Stability. Nanomaterials 2018, 8, 38. [CrossRef] [PubMed]

93. Liu, J.; Yin, J.; Feng, B.; Xu, T.; Wang, F. Enhanced Electrocatalytic Activity and Stability toward the Oxygen Reduction Reaction with Unprotected Pt Nanoclusters. Nanomaterials 2018, 8, 955. [CrossRef] [PubMed]

94. Ao, X.; Zhang, W.; Li, Z.; Lv, L.; Ruan, Y.; Wu, H.H.; Chiang, W.H.; Wang, C.; Liu, M.; Zeng, X.C. Unraveling the High-activity Nature of Fe-N-C Electrocatalysts for the Oxygen Reduction Reaction: The Extraordinary Synergy between $\mathrm{Fe}-\mathrm{N}_{4}$ and $\mathrm{Fe}_{4} \mathrm{~N}_{4}$. J. Mater. Chem. A 2019, 7, 11792-11801. [CrossRef]

95. Kong, Z.; Maswadeh, Y.; Vargas, J.A.; Shan, S.; Wu, Z.P.; Kareem, H.; Leff, A.C.; Tran, D.T.; Chang, F.; Yan, S.; et al. Origin of High Activity and Durability of Twisty Nanowire Alloy Catalysts under Oxygen Reduction and Fuel Cell Operating Conditions. J. Am. Chem. Soc. 2020, 142, 1287-1299. [CrossRef] [PubMed] 
96. Dong, Y.; Deng, Y.; Zeng, J.; Song, H.; Liao, S. A High-performance Composite ORR Catalyst Based on the Synergy between Binary Transition Metal Nitride and Nitrogen-doped Reduced Graphene Oxide. J. Mater. Chem. A 2017, 5, 5829-5837. [CrossRef]

97. Li, J.; Sharma, S.; Liu, X.; Pan, Y.T.; Spendelow, J.S.; Chi, M.; Jia, Y.; Zhang, P.; Cullen, D.A.; Xi, Z.; et al. Hard-Magnet L10-CoPt Nanoparticles Advance Fuel Cell Catalysis. Joule 2019, 3, 124-135. [CrossRef]

98. Kirsanova, M.A.; Okatenko, V.D.; Aksyonov, D.A.; Forslund, R.P.; Mefford, J.T.; Stevenson, K.J.; Abakumov, A.M. Bifunctional OER/ORR catalytic activity in the tetrahedral $\mathrm{YBaCo}_{4} \mathrm{O}_{7.3}$ oxide. J. Mater. Chem. A 2019, 7, 330-341. [CrossRef]

99. Yang, X.; Zhang, G.; Du, L.; Zhang, J.; Chiang, F.K.; Wen, Y.; Wang, X.; Wu, Y.; Chen, N.; Sun, S. PGM-Free Fe/N/C and Ultralow Loading Pt/C Hybrid Cathode Catalysts with Enhanced Stability and Activity in PEM Fuel Cells. ACS Appl. Mater. Interfaces 2020, 12, 13739-13749. [CrossRef]

100. Proietti, E.; Jaouen, F.; Lefèvre, M.; Larouche, N.; Tian, J.; Herranz, J.; Dodelet, J.P. Iron-based cathode catalyst with enhanced power density in polymer electrolyte membrane fuel cells. Nat. Commun. 2011, 2, 416. [CrossRef]

101. Lee, J.M.; Han, H.; Jin, S.; Choi, S.M.; Kim, H.J.; Seo, M.H.; Kim, W.B. A Review on Recent Progress in the Aspect of Stability of Oxygen Reduction Electrocatalysts for Proton-Exchange Membrane Fuel Cell: Quantum Mechanics and Experimental Approaches. Energy Technol. 2019, 7, 1900312. [CrossRef]

102. Zhao, X.; Takao, S.; Higashi, K.; Kaneko, T.; Samjeskè, G.; Sekizawa, O.; Sakata, T.; Yoshida, Y.; Uruga, T.; Iwasawa, Y. Simultaneous Improvements in Performance and Durability of an Octahedral $\mathrm{PtNi}_{x} / \mathrm{C}$ Electrocatalyst for Next-Generation Fuel Cells by Continuous, Compressive and Concave Pt Skin Layers. ACS Catal. 2017, 7, 4642-4654. [CrossRef]

103. Lopes, P.P.; Li, D.; Lv, H.; Wang, C.; Tripkovic, D.; Zhu, Y.; Schimmenti, R.; Daimon, H.; Kang, Y.; Snyder, J.; et al. Eliminating dissolution of platinum-based electrocatalysts at the atomic scale. Nat. Mater. 2020, 19, 1207-1214. [CrossRef] [PubMed]

104. Li, J.; Sougrati, M.T.; Zitolo, A.; Ablett, J.M.; Oğuz, I.C.; Mineva, T.; Matanovic, I.; Atanassov, P.; Huang, Y.; Zenyuk, I.; et al. Identification of durable and non-durable $\mathrm{FeN}_{x}$ sites in $\mathrm{Fe}-\mathrm{N}-\mathrm{C}$ materials for proton exchange membrane fuel cells. Nat. Catal. 2021, 4, 10-19. [CrossRef]

105. Mølmen, L.; Eiler, K.; Fast, L.; Leisner, P.; Pellicer, E. Recent advances in catalyst materials for proton exchange membrane fuel cells. APL Mater. 2021, 9, 040702. [CrossRef] 